\title{
A new genus and species of leaf miner (Lepidoptera, Gracillariidae) for Chile associated to the native tree Lithraea caustica
}

\author{
Enrique A. Mundaca ${ }^{1}$, Luis E. Parra² \& Héctor A. Vargas ${ }^{3}$
}

\author{
${ }^{1}$ Universidad Católica del Maule, Facultad de Ciencias Agrarias y Forestales, Escuela de Agronomía, Casilla 7-D, Curicó, Chile. emundaca@ucm.cl \\ ${ }^{2}$ Departamento de Zoología, Facultad de Ciencias Naturales y Oceanográficas, Universidad de Concepción. Casilla 160-C, Concepción, Chile. \\ luparra@udec.cl \\ ${ }^{3}$ Departamento de Recursos Ambientales, Facultad de Ciencias Agronómicas, Universidad de Tarapacá, Casilla 6-D. Arica, Chile. havargas@uta.cl
}

\begin{abstract}
A new genus and species of leaf miner (Lepidoptera, Gracillariidae) for Chile associated to the native tree Lithraea caustica. We propose the new genus and species of Gracillariidae (Lepidoptera) Hualpenia lithraeophaga Mundaca, Parra \&Vargas gen. nov., sp. nov., leaf miner of Lithraea caustica (Mol.) H. et Arn (Anacardiaceae) occurring in southern central Chile. Aspects of the life cycle, adult and larval morphology, development and feeding habits of the new genus and species are also presented. We emphasise the uniqueness and importance of this new species for broadening the current knowledge on the Chilean fauna of Gracillariidae.
\end{abstract}

KEYWORDS. Hualpén, hypermetamorphic, Insecta.

The family Gracillariidae includes small-sized moths with white marks on the wings and is considered the main group of lepidopteran leaf-miners in the world (Davis 1987). Most species of this family have a remarkable larval development characterised by having at least two well-differentiated morphological stages, although authors such as Trägardh (1913) recognise up to four different stages. This type of development, with differentiated larval stages, has been called hypermetamorphosis or heteromorphic development (Hinton \& Mackerras 1970; Kumata 1978; Wagner et al. 2000). The first stages are normally a flat-shaped larva with ambulatory callosities instead of properly developed legs, simplified chaetotaxy and highly modified mandibles. These specialised mandibles are generally "scissor-like" shaped and serve to saw the plant tissue, separating the cuticle from the epidermis. These early stages are characteristically sap feeding. The second developmental stages have the typical eruciformshaped caterpillar, typical of the order Lepidoptera, with conspicuous legs and prolegs, a spinneret and well-developed chewing mandibles to feed on tissues. This larval stage has been called a "tissue feeding form" (Trägardh 1913).

The latest checklist of Neotropical Gracillariidae indicated a total of 179 species distributed in this region (De Prins \& De Prins 2012). Some of these species have been described in recent taxonomic contributions (e.g. Davis \& Wagner 2005, 2011; Vargas \& Landry 2005; Vargas \& Parra 2005; Landry 2006; Kawahara et al. 2009). However, further additional fieldwork is required to obtain better records and to increase the understanding of the evolutionary history of this interesting fauna.

The Chilean native fauna of Gracillariidae is relatively unknown, with only five native species described so far (De Prins \& De Prins 2012): Parectopa rotigera Meyrick, 1931,
Prophyllocnistis epidrimys Davis, 1994, whose larvae are leaf miners of the native plant Drimys winteri J.R. et G. Forst, 1776 (canelo); Phyllocnistis puyehuensis Davis, 1994; Chileoptilia yaroella Vargas \& Landry, 2005; and Angelabella tecomae Vargas \& Parra, 2005. The introduced pest species Phyllocnistis citrella Stainton, 1856 is restricted to the northern coastal valleys associated with citrus plantations.

The VIII Region of Chile, which includes the Hualpén Peninsula (Fig. 1), is a transitional area where two different forest communities overlap and become in contact (Polymeris 1995). These two types of communities are the sclerophyllous forest, part of the Mediterranean zone (which comes from the north), and the hygrophyllous forest, a vegetation type that characterises the sub-Antarctic area. In this transitional area, the vegetation acquires a particular pattern, which is different from the two main zones. The dominant tree species are: Cryptocarya alba (Mol.) Looser, 1782 (peumo), Aextoxicon punctatum Ruiz \& Pav (olivillo), L. caustica (litre) and Peumus boldus Molina, 1782 (boldo). The Hualpén forest should be considered the northern limit of the Valdivian forest, although the main characteristics of the forest remain mainly sclerophyllous. There are 19 different vegetation types described for Hualpén Peninsula by Polymeris (1995) that include a wide variety of different habitats, ranging from grasslands and artificial plantations to secondary growth patches of fragmented native forest and shrubs. Lithraea caustica (Mol.) H. et Arn has been described as the dominant species of at least 5 vegetation types described for the peninsula (Polymeris 1995). In addition, L. caustica is a shrub that belongs to the Anacardiaceae family, whose species are typical of the Matorral Maulino (Maulean thicket), which is dominated in its higher strata by sclerophyllous species (Hoffman 1982). The species of this family are characterised 
by having thick, resin-like sap juices which are frequently caustic or poisonous (Cabrera 1938) and are known for provoking allergic reactions on humans.

The aim of this study is to describe and provide biological background information of a new genus and species of Gracillariidae for the Chilean fauna of leaf miners associated with the native tree Lithraea caustica.

\section{METHODS}

Sampling was carried out in the Hualpén Peninsula, $36^{\circ} 45^{\prime} \mathrm{S}-73^{\circ} 13^{\prime} \mathrm{O}$ (Fig. 1) between March and November, 1997. We collected infected leaves by inspecting $L$. caustica trees in the field. Leaves containing larvae were collected from the plant and kept in plastic bags to be transported to the laboratory. Larvae utilised for character description were fixed in alcohol 70\%. A number of larvae were kept alive inside the leaves in order to rear them into adults. Damages on the leaves were photographed to show the type of damage provoked by the different larval stages. Electronic microscope pictures were taken in the Scanning Electron Microscope (SEM) laboratory of the Universidad de Concepción, Chile.

Examined material is deposited in the Museo de Zoología Universidad de Concepción (MZUC), Concepción, Chile. The female genitalia is not illustrated since the slide containing its preparation was lost during the 2010 earthquake in Chile.

\section{TAXONOMY}

\section{Hualpenia Mundaca, Parra \& Vargas gen. nov.}

Type species: Hualpenia lithraeophaga Mundaca, Parra \& Vargas sp. nov.

Diagnosis. Among the Neotropical genera, Hualpenia is similar to Eucosmophora Walsingham, 1897, by the presence of a digitate lobe on the costal margin of the valva in the male genitalia. However, the veins $\mathrm{R}_{5}$ and $\mathrm{M}_{1}$ are separate on the forewings of Eucosmophora, meanwhile these veins are stalked in Hualpenia. Veins $\mathrm{R}_{5}$ and $\mathrm{M}_{1}$ are also separate in the forewings of other non-Neotropical genera with similar digitate lobe on the costal margin of the valve: Amblyptila Vári, 1961, Borboryctis Kumata \& Kuroko, 1988, Gibbovalva Kumata \& Kuroko, 1988, Melanocercops Kumata \& Kuroko, 1988, Phodoryctis Kumata \& Kuroko, 1988, and Sauterina Kuznetsov, 1979. Among the Neotropical genera, veins $\mathrm{R}_{5}$ and $\mathrm{M}_{1}$ are stalked in Chileoptilia Vargas \& Landry, 2005; however, the morphology of the male genitalia is remarkably different, lacking a digitate lobe on the costal margin of the valve. The same is true when comparing Hualpenia with other nonNeotropical genera with stalked $\mathrm{R}_{5}$ and $\mathrm{M}_{1}$.

Description. Small moths with 10-11 mm forewing length (Fig. 2). Forewings colour brown cooper, lanceolated, with white marks on the distal three-quarters. Hindwings fringed, grey coloured, shorter than the forewings. Forewing venation with all veins present (Fig. 5A). Base of R3, R4, R5+M1 and M2 not differentiated; distal margin of discal cell slightly differentiated. $\mathrm{R}_{5}$ extended towards apex; $\mathrm{A}_{1+2}$ and $\mathrm{CuP}$ weak,

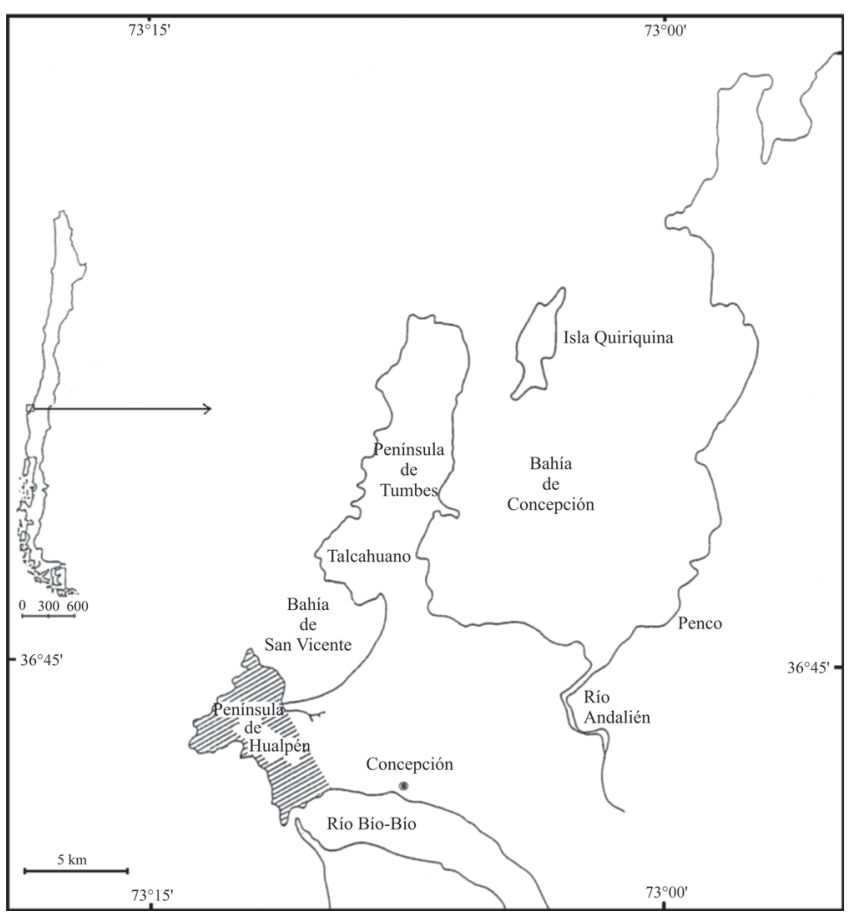

Fig. 1. Hualpén Peninsula map.

poorly marked; $\mathrm{M}_{1}$ fused with $\mathrm{R}_{5}$. Hindwing venation with $\mathrm{Sc}+\mathrm{R}_{1}, \mathrm{R}_{5}$ and $\mathrm{Cu}_{2}$ present. Male genitalia with a digitate lobe in the costal margin of the valve. Hypermetamorphic larva with leaf miner habits. First larval instars flat shaped, sap feeders, forming serpentine mines (Fig. 3A), with ambulatory callosities instead of legs and prolegs. Later instars, larva eruciform tissue-feeding forming patchy mines (Fig. 3B). Last instar larva changes its colour from pale white-grey to dark pink prior to pupation. The cocoon remains inside the mine, surrounded by a silk chamber until the adult emerges.

\section{Hualpenia lithraeophaga Mundaca, Parra \& Vargas sp.nov.}

Description. Male. Head. Head roughly short haired (Fig. 4A). With a tuft of hairs, directed forward and coming out from the lateral margins of the forehead, under the antennae. Face smooth, covered by white scales. Labial palpus covered by white scales which become dark brown towards the last two segments. Ocelli absent. Haustellum covered with setae (Fig. 4B). Maxillary palpus covered with scales, shorter than distal segment of labial palpus. Distal segment of the labial palpus same length of the compound eye's diameter. Filiform antennae. Pillifers present. Thorax. Light brown coloured. Ventral area dark brown with two bands of white scales covering pro and mesothorax long each side. Legs long and slender. Forewing brown-silver lanceolated, apical region dark cooper-ferruginous with a white semicircular band on the distal threequarters; a smaller white mark also present, closer to the apical region of the wing. Distal border of the wing black coloured. Hindwings grey-silver, lighter, shorter than the forewings with a uniform colour pattern (Fig. 2). Female with a frenulum con- 

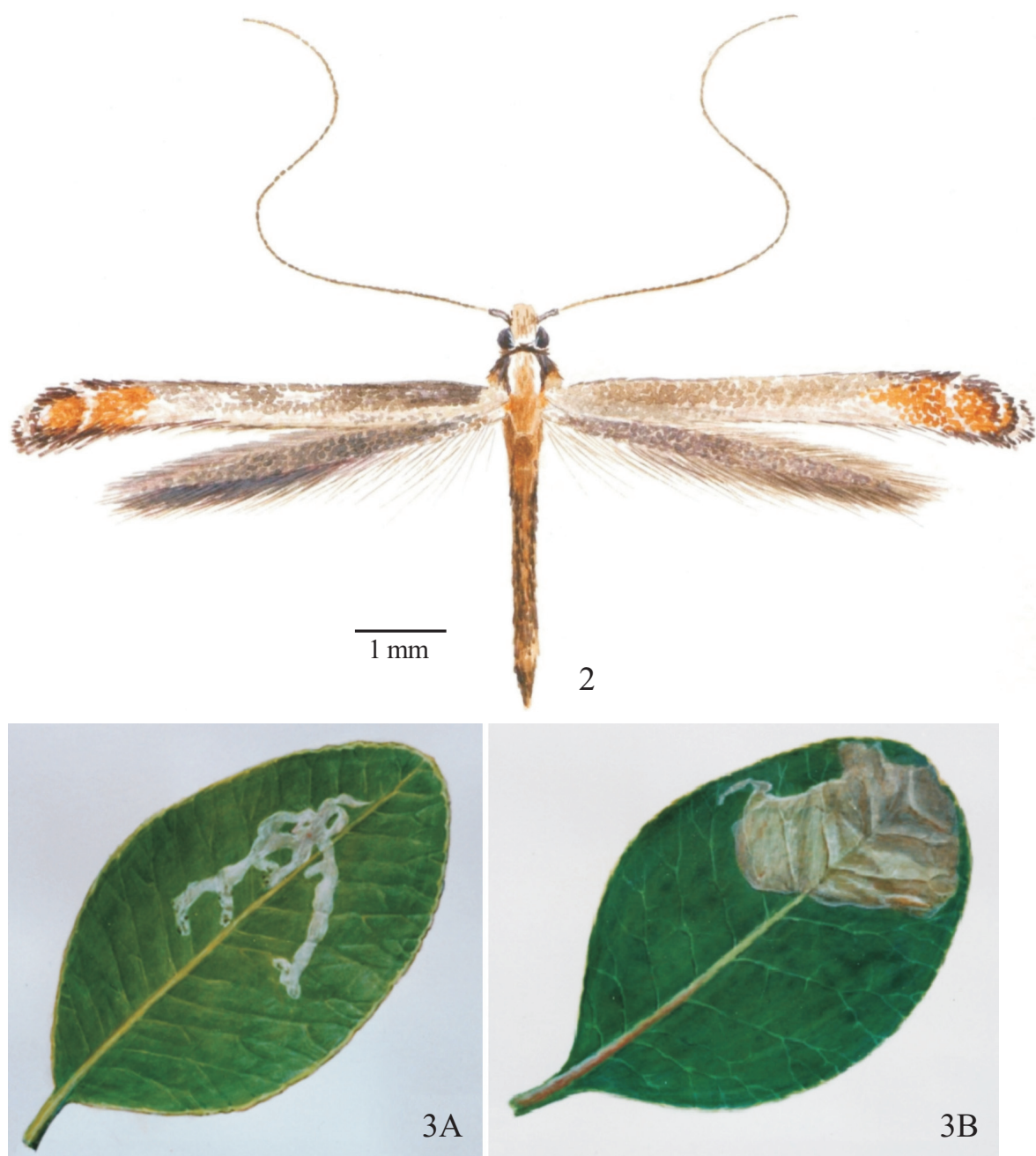

Figs. 2-3. 2. Hualpenia lithraeophaga sp. nov., holotype male adult, $11 \mathrm{~mm}$ wingspan. 3. Leaf damage provoked by sap-feeding larva (A) and by tissue feeding larva (B) of Hualpenia lithraeophaga sp. nov.

sisting of two setae. Male with frenulum consisting of only one setae. Distal portion of the hindwings fringed. Abdomen. Dorsal area dark brown coloured; ventral area light brown to yellowish; A8 membranous, covered with a ventral band of white scales. Genitalia. Dorsal arms of the saccus "V" shaped. Valve four times longer than wide, hairy towards apex. Medial process slightly bent. Short, digitate lobe arising near $1 / 4$ costa. Saccus subtriangular, rounded towards apex. Uncus and transtilla absent. Tegumen subtriangular enlarged, weakly sclerosed. Coremmata absent. Aedeagus long, same length than valve. No cornuti (Fig. 5B).

Female. Similar to male, but abdomen with ventral area grey silver, without the band of white scales on the eight segment. Papillae analis covered by long setae (Fig. 4C).

Type Material. Holotype male (Fig. 2), December 7, 1999 (MZUC); Allotype female, November 25, 1999 (MZUC). Paratype: 1 female, November 25, 1999 (used for the electron microscope preparation). Holotype, allotype and paratype were reared in the laboratory from larvae collected at Parque Botánico (Universidad de Concepción), in Hualpén Peninsula, VIII Región, Chile. Enrique Mundaca leg. Material deposited at MZUC.
Additional Examined material. One male, December 7, 1998; two females reared on January 14, 1999. One of the females was utilised to describe wing venation and genitalia preparation. A second female specimen was used for the Scanning Electron Microscope (SEM) analysis. All specimens obtained from larvae collected by Enrique Mundaca at the type locality. Material deposited at MZUC.

Sap-feeding instar larva. Leaf miner of Lithraea caustica. Head light brown coloured. Body white to light brown, with plates of micro spines on the dorsal and ventral region of segments T1-T3 and A1-A9 (Fig. 6A, 6C and 6D). Body and cephalic capsule depressed (Fig. 6A, 7A and 7B). Ambulatory callosities present in thorax and abdomen (Fig. 6E and 7B). Scissor-like mandibles, horizontally arranged (Fig. 6F) with irregular saw-like borders (Fig. 6B). Spinneret not observed. Reduced chaetotaxy.

Tissue feeding larva. Head. Hypognatus head (Fig. 8A). Spinneret present (Fig. 8B). Ocular area with 4 distinct stemmata (Fig. 8C). Setae A1, A2 and A3 present. A1 to the same distance from stemma4 than A2 from stemmata 2 and 3. A3 located half a distance from stemma1. SS2 laterally located behind stemma1 in front of stemma2. SS3 ventrally located, 

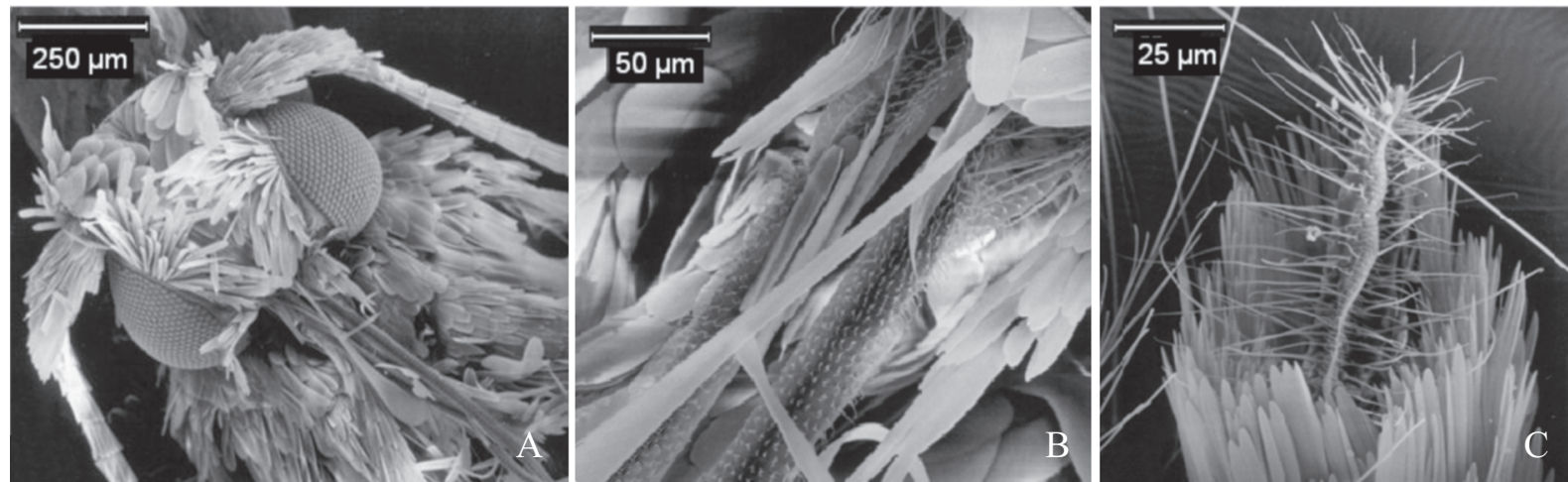

Fig. 4. Hualpenia lithraeophaga sp. nov. (A) Adult head, ventral-front view. (B) Proboscis. (C) Papillae analis covered by setae.

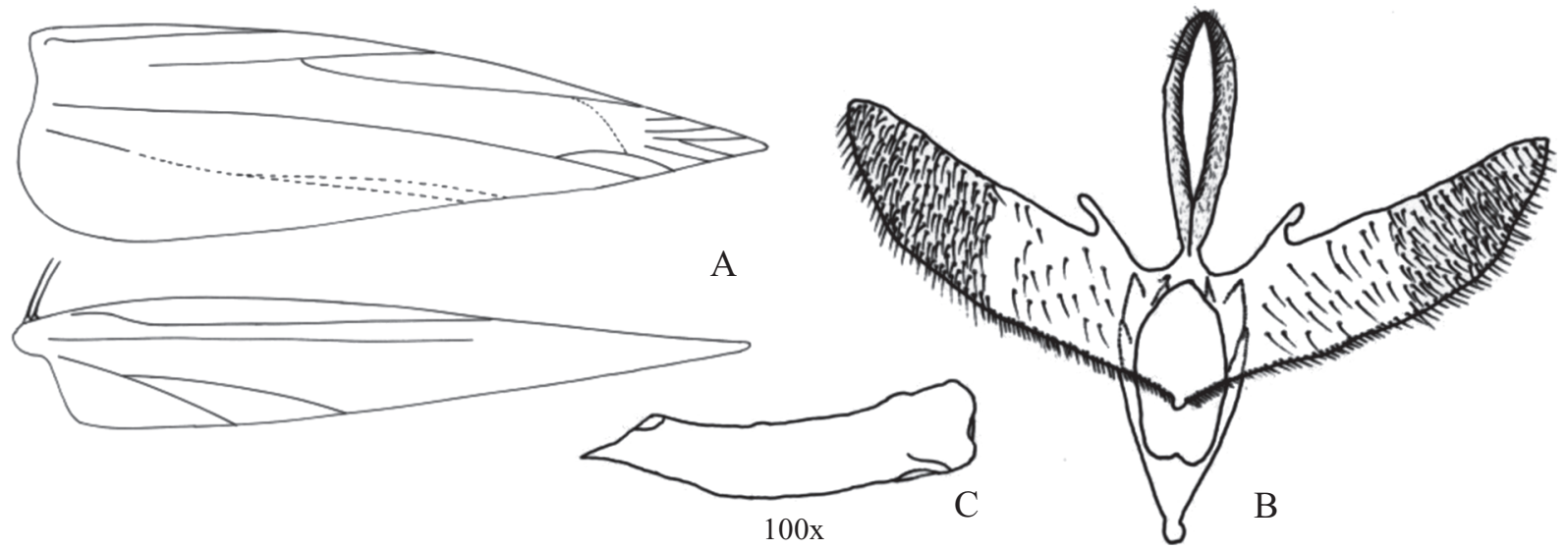

Fig. 5. Hualpenia lithraeophaga sp. nov. (A) Wing venation. (B) Male genitalia ventral view, and (C) aedeagus left view.
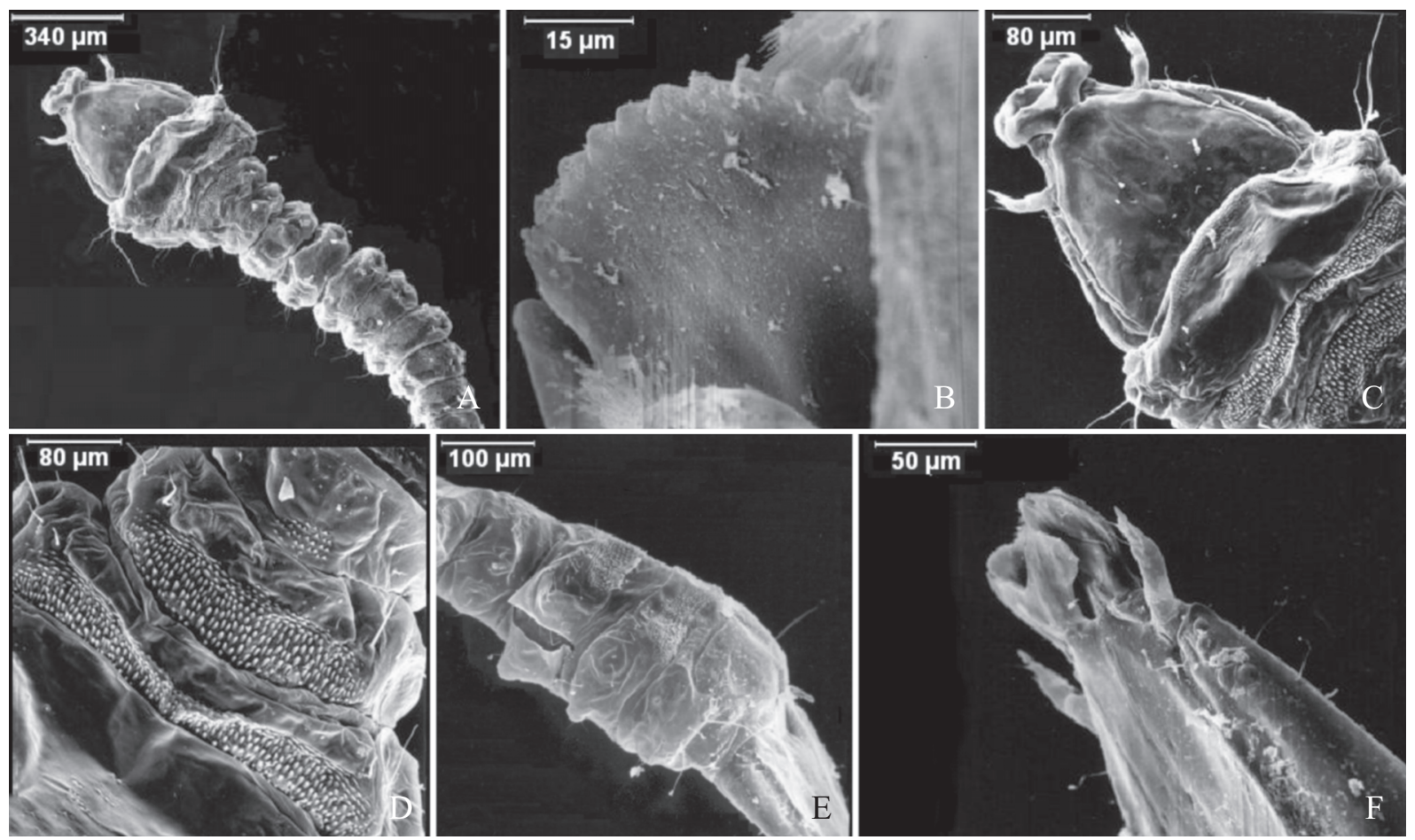

Fig. 6. Hualpenia lithraeophaga sp. nov. (A) Dorsal view of sap-feeding larva. (B) Details of the scissor-like mandible in the sap-feeding larva. (C) Sapfeeding larva, dorsal view of the head capsule. (D) Dorsal view of plates covered with micro spines present on thoracic segments of the sap-feeding larva. (E) Lateral view of partially developed legs. (F) Lateral view of the scissor-like mandibles present on the sap-feeding larva. 

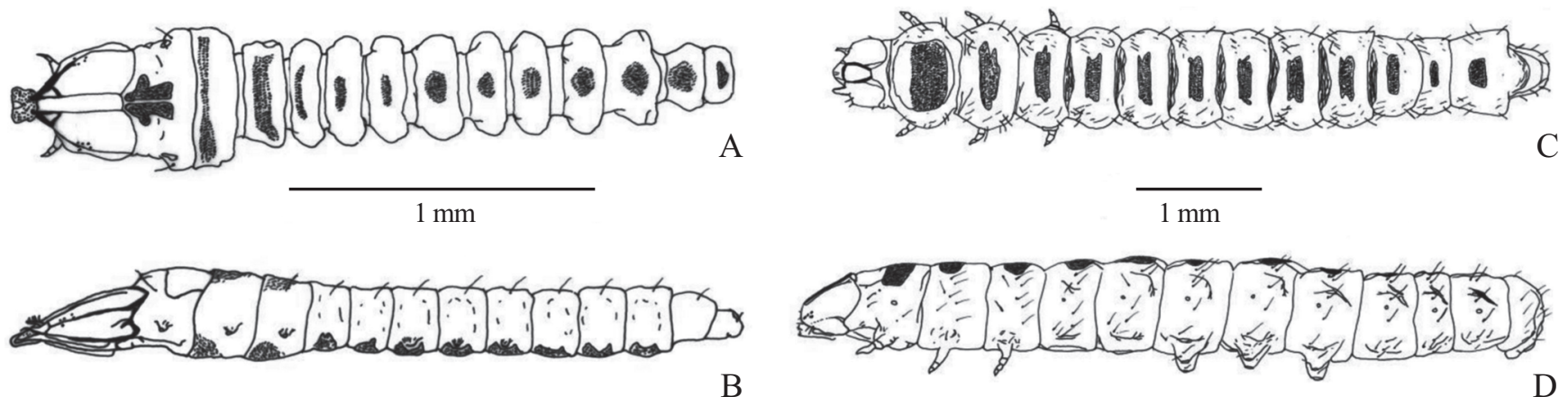

Fig. 7. Hualpenia lithraeophaga sp. nov. (A) Dorsal view of sap-feeding larva. (B) Lateral view of sap-feeding larva. (C) Tissue feeding larva. (D) Lateral view of tissue feeding larva.

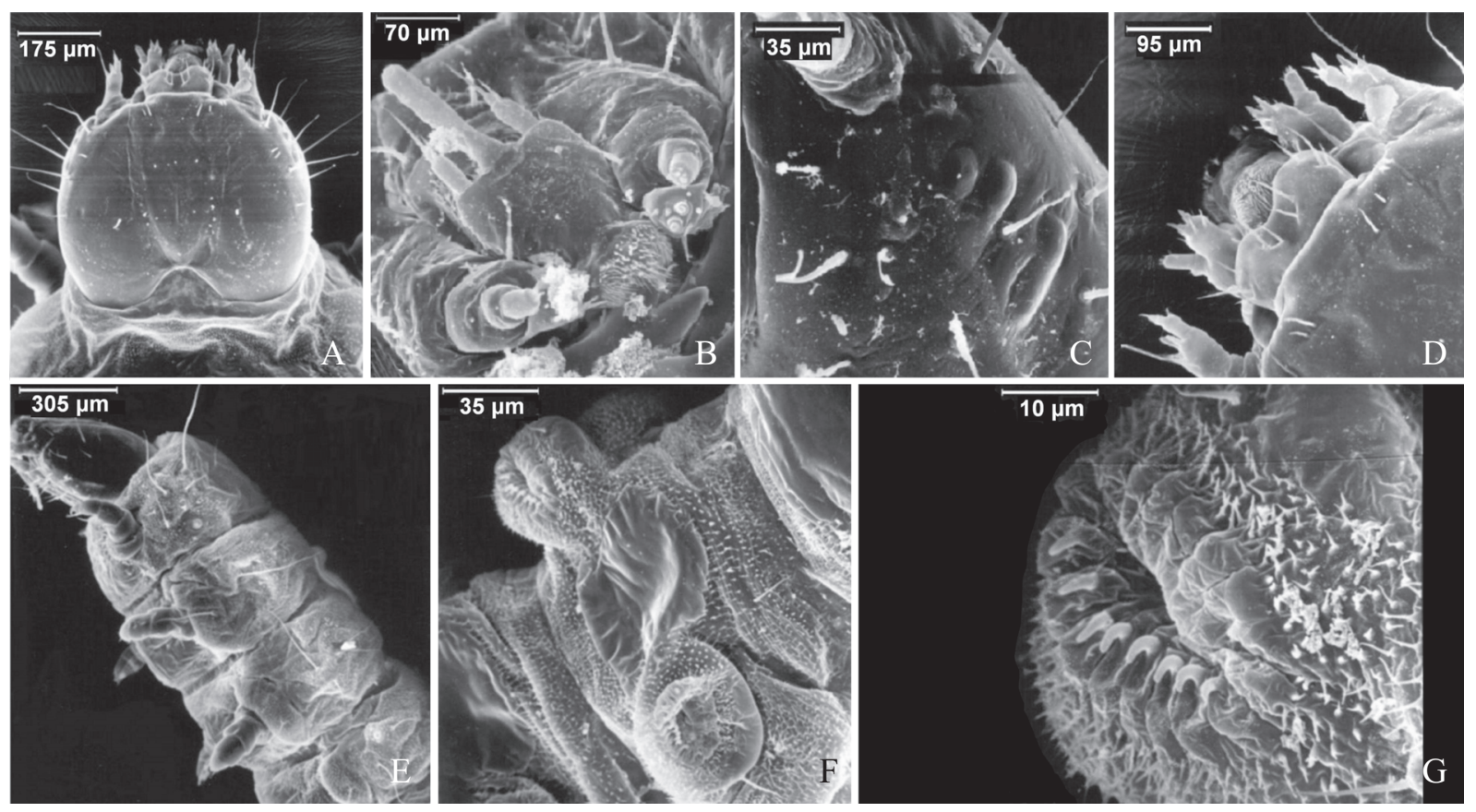

Fig. 8. Hualpenia lithraeophaga sp. nov. (A) Dorsal view of the head of the tissue-feeding larva. (B) Tissue-feeding larva, maxillae and labium. (C) Detail of the ocular area of the tissue-feeding larva. (D) Frontal detail of the head of the tissue-feeding larva. (E) Lateral view of tissue-feeding larva legs. (F) Ventral view of prolegs. (G) Details of the crochets.

surrounded bystemma4. L1 present, shorter than A3. C1 and $\mathrm{C} 2$ present on the Clypeus. C1 one third the length of $\mathrm{C} 2$ (Fig. 8D). Thorax. Prothorax. D1 present on the cervical shield. SD1, SD2 and D2 absent. Complex L1 and L2 present. L1 located above the spiracle and closer to L2 than D1. L2 located under the spiracle. SV1 present, twice longer than L1 and L2 (Fig. 9A). Mesothorax and metathorax. D1, D2, SD1 and SD2 on the mesothoracic shield. L1 same length than L2. SV1 present, 1.5 times longer than L1 and L2. Spiracle absent. Legs well developed (Fig. 10B, 11B, 21 and 22). Abdomen. Spiracles absent in A9 and A10. D1, D2 and SD1 present in all other abdominal segments (A1-8). SD2 present only in A3. SD3 present only in A10. L1 occurring in all segments, always ventrally oriented to the spiracle.L2 three quarters the length of L1, present in A1 and A2.SV1and SV2 absent from A10. SV3 absents from A1, A9 and A10. V1 present from A3 to A6 (Fig. 9A). Prolegs with only one row of uniordinal crochets arranged in an uniordinal manner following criteria established by Stehr (1987) (Fig. 8F and 8G).

Examined material. One larva, collected on April 15, 1997, 5 larvae collected on May 28, 1997, 1 larva collected on June 27 1997, 2 larvae collected on September 26, 1997. All specimens collected at Parque Botánico (Universidad de Concepción) Hualpén Peninsula, VIII Región, Chile, Enrique Mundaca leg. Material deposited at MZUC.

Pupa. Obtecta type. Maximum length $5 \mathrm{~mm}$. Maximum diameter $1 \mathrm{~mm}$. Integument dark brown. Antennae about $1 / 5$ longer than the body. Frontal process (cocoon cutter) short, slightly pointed towards apex. Labial palpi visible. Galea shorter than forewings. Forewings extending almost to A7, parallel, not sealed in front of the body. Middle and hind legs visible, partially covered by the forewings (Fig. 9B). 

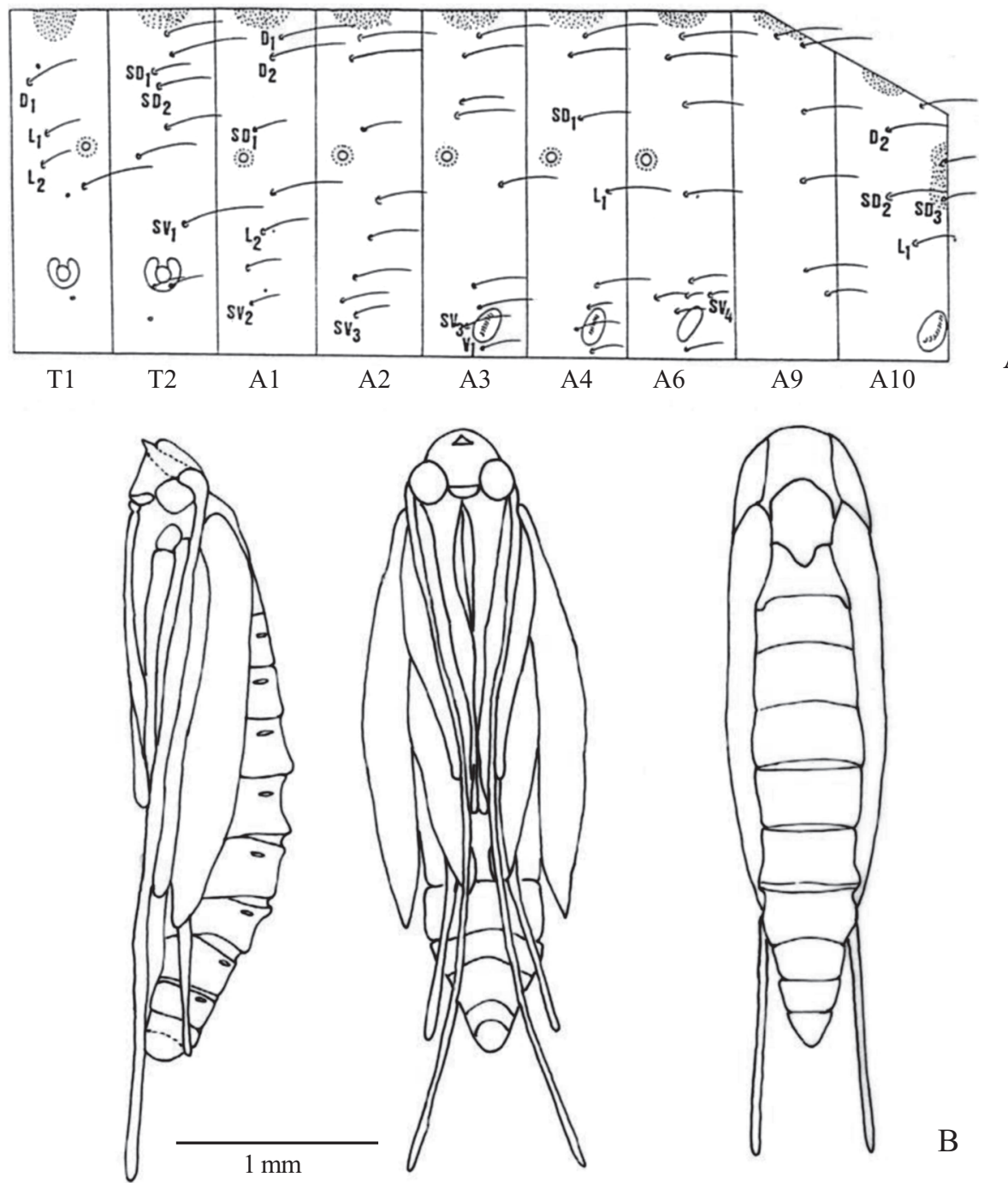

A

Fig. 9. Hualpenia lithraeophaga sp. nov. (A) Chaetotaxy of thoracic segments: 1-2; and abdominal segments: 1, 2, 3, 4, 6, 9 and 10. (B) Pupa, lateral, ventral and dorsal view.

Examined material. One pupa collected on August 1989, at Parque Botánico (Universidad de Concepción) Hualpén Peninsula, VIII Region Chile, Hector Ibarra leg. Material deposited at MZUC.

Egg. Unknown.

\section{BIOLOGY}

So far, it has not been possible to collect eggs in the field. Marks left on the leaves and the number of larvae found in the leaves show that there is just one egg laid on the adaxial surface of the leaf. Only in one occasion we have observed a mine in the abaxial surface. The larva inside was dead and at the sap-feeding instar.

Body structure of the last larval instar differs from other species of the family, such as those of the genera Marmara Clemens, 1863, (Fitzgerald \& Simeone 1971) and Prophyllocnictis Davis, 1994, where the second developmental stage does not feed and belongs to the spinning type (Kumata 1978) and resembles a typical eruciform lepidopteran larva. Prior to the pupation, the larva suffers a remarkable change of its colour, from pale grey to dark pink. This phenomenon has been observed during late winter-early spring season, at the beginning of September. Pupation occurs inside the mine, although this observation was carried out in controlled laboratory conditions. No cocoons or pupae have been observed inside the leaf mine in the field.

Phenology. Our observations in the field indicate that the life cycle of this species is univoltine, with adults flying during late spring and early summer (Table I). Although it is possible to observe mines throughout the year, many of them were observed with dead larvae inside the galleries. Dead larvae are easy to identify because of the colour of the mines as they become pale grey. Table I shows the records of different stages of the species and the month that have been recorded to be occurring in the field. These results are based on the observation of living larvae inside the mines.

Leaf damage pattern. There are basically two types of mines produced by the larvae. Serpentine mines (Fig. 3A) are 
Table I. Phenology of Hualpenia lithraeophaga Mundaca, Parra \& Vargas.

\begin{tabular}{|c|c|c|c|c|c|c|c|c|c|c|c|c|}
\hline \multirow{2}{*}{ Stages } & \multicolumn{12}{|c|}{ Months } \\
\hline & Jan & Feb & Mar & Apr & May & Jun & Jul & Aug & Sep & Oct & Nov & Dec \\
\hline Egg & $?$ & $?$ & $?$ & & & & & & & & & \\
\hline Larva & & & & $\mathrm{X}$ & $\mathrm{X}$ & $\mathrm{X}$ & $X$ & $\mathrm{X}$ & $X$ & & & \\
\hline Pupa & & & & & & & & $\mathrm{X}$ & $X$ & $\mathrm{X}$ & & \\
\hline Adult & $?$ & $?$ & & & & & & & & & $X$ & $X$ \\
\hline
\end{tabular}

produced by the sap-feeding instars. This type of leaf mine is pale coloured and characterised for not having the cuticle too separated from the parenchyma. At this stage the mine looks narrow, whitish in colour, serpentine-shaped and flat. The second type of mine has a patch shape (Fig. 3B). It occurs after the hypermetamorphosis of the larva, when the larva changes its feeding habits and morphs to a tissue-feeding larva type. At this stage the mine looks externally brownish, with the leaf cuticle clearly separated from the parenchyma giving the leaf a swollen appearance. It is common to observe in the field leaves with the cuticle broken without the larva inside. When examining the interior of the mine, it is possible to find rests of head capsules and droppings of the larvae.

\section{DISCUSSION}

The characteristics of this new genus allow locating it in the subfamily Gracillariinae. The most important characters described by Davis \& Robinson (1999), as representative of Gracillariinae, are present in this species: adults raised at steep angle while perching, Rs archers towards Sc, eighth abdominal segment membranous in the male, and A9 with bisetose (D1-D2) complex in the tissue-feeding larva. We compared head, thorax and male genitalia characters of this genus with those described for the type species of genera of Gracillariinae proposed by Davis \& Robinson (1999) and described by Vari (1961). The head-scales arrangement in Hualpenia is more similar to Epicephala Meyrick, 1880, and Aristaea Meyrick, 1907, but it differs from Aristaea in that it does not have ocelli. Maxillar and labial palpi seem to follow the pattern proposed for most of the representative genera of Gracillariinae, where labial palpi are longer and more conspicuous than the maxillary palpi. Male genitalia of Hualpenia, compared to that of other genera of Gracillariinae, does not show the presence of coremmata. However, this character does not exclusively belong to Hualpenia, as for at least in three other genera of Gracillariinae, namely, Eucosmophora Walsingham, 1897, and Schedocercops Vári, 1961 , the presence of coremmata was not reported.

This genus differs from most Gracillariinae in that the last instar changes its colour, from pale white-grey to dark pink prior to pupation. Another remarkable character of Hualpenia is the presence of a ventral band of white scales covering the male's 8th abdominal segment which is not present in the female's abdomen. Thus, Hualpenia can be defined mainly by a combination of characters, which cannot be found in other genera of Gracillariinae.
Hualpenia lithraeophaga is the first Chilean Gracillariidae with larvae associated with Anacardiaceae. Previous host plant record for the Chilean fauna were restricted to the plant families Bignoniaceae (Vargas \& Parra 2005), Fabaceae (Vargas \& Landry 2005), Malvaceae (Vargas et al. 2013) and Winteraceae (Davis 1994). Host plant association with Anacardiaceae has been previously mentioned for other three species of South American Gracillariidae in the genera Caloptilia Hübner, 1825 , Eucosmophora Walsingham, 1897, and Leurocephala Davis \& McKay, 2011 (Davis et al. 2011), with most surveys for Gracillariidae on South American Anacardiacaeae directed to the Brazilian Pepper Tree, Schinus terebinthifolius Radii, 1820. The genus Lithraea has been also reported as host plant for two of these species: Caloptilia schinusifolia Davis \& Wheeler, 2011, and Eucosmophora schinusivora Davis \& Wheeler, 2011 (Davis et al. 2011).

The finding of this remarkable species enhances the necessity for conserving the last remnants of native vegetation on the Hualpén Peninsula. As mentioned before, this is the last relict of transitional schlerophyllous-latifoliated evergreen forest of Chile (Gajardo 1994; Polymeris 1995) and is considered also a unique ecosystem in the world. The Hualpén Peninsula is currently under an accelerated process of change, mainly due to economic activities (Martinez \& Donoso 1997) such as urbanisation, construction of recreational spaces and forestry. Such changes do not consider important the protection of the natural uniqueness of an area that could be the potential refuge of a number of unknown species.

\section{ACKNOWLEDGEMENTS}

We would like to thank all those people that have helped us to carry out this research: to Dr. Viviane Jerez, Dr. Thomas Ogden, Minerva Contreras, Patricia Bocaz, Romina Villagrán and María de Los Ángeles, many thanks for your help in our field trips and laboratory work. To Hipólito Rifo and Gabriel Mendoza for preparing the adult and larvae figures. To Mario Moya for edition of the electronic figures. We would also like to thank the personnel in charge of the Scanning Electron Microscope for their help during the preparation of the samples and Mariana Lazzaro-Salazar for her help with the figures' edition.

\section{REFERENCES}

Cabrera, A. 1938. Revisión de las Anacardiáceas Austroamericanas. Revista del Museo La Plata. Sección Botánica 2: 3-64.

Davis, D.R. \& Robinson, G.S. 1999. The Tineoidea and Gracillarioidea, p. 91-117. In: Kristensen, N.P. (ed.). Handbook of Zoology, Lepidoptera, Moths and Butterflies, vol. 1 Evolution, Systematics and Biogeography. Berlin \& New York, Walter de Gruyter, $x+491$ p.

Davis, D.R. \& Wagner, D.L. 2002. Biology and systematics of the Neotropical leafminer genus Eucosmophora (Lepidoptera: Gracillariidae). Tropical Lepidoptera 13: $1-40$.

Davis, D.R. \& Wagner, D.L. 2011. Biology and systematics of the New World Phyllocnistis Zeller leafminers of the avocado genus Persea (Lepidoptera, Gracillariidae). Zookeys 97: 39-73. 
Davis, D.R. 1987. Gracillariidae, p. 372-374. In: Stehr, F.W. (ed.). Immature insects, vol. 1, Dubuque, Kendall/Hunt publishing Company, ii+755 p.

Davis, D.R. 1994. New leaf-mining moths from Chile, with remarks on the history and composition of Phillocnistinae (Lepidoptera: Gracillariidae). Tropical Lepidoptera 5: 65-75.

Davis, D.R., McKay, F., Oleiro, M., Vitorino, M.D. \& Wheeler, G.S. 2011. Biology and systematics of the leaf mining Gracillariidae of Brazilian Pepper Tree, Schinus terebenthifolius Raddi, with descriptions of a new genus and four new species. Journal of the Lepidopterists' Society 65: 61-93.

De Prins, J. \& De Prins, W. 2012. Global taxonomic database of Gracillariidae (Lepidoptera). Available at: http://www.gracillariidae.net (accessed 21 August 2012)

Fitzgerald, T.D. \& Simeone, J.B. 1971. Serpentine miner Marmara fraxinicola (Lepidoptera: Gracillariidae) in stems of white ash. Annals of the Entomological Society of America 64: 770-773.

Gajardo, R. 1994. La vegetación natural de Chile: clasificación y distribución geográfica. Santiago, Editorial Universitaria, 314 p.

Hinton, H.E. \& Mackerras, I.M. 1970. Reproduction and metamorphosis, p. 83-106. In: CSIRO (ed.). The insects of Australia. Carlton, Melbourne University Press.

Hoffman, A. 1982. Flora Silvestre de Chile, Zona Araucana. Santiago, Fundación Claudio Gay, ii+258 p.

Kawahara, A.Y., Nishida, K. \& Davis, D.R. 2009. Systematics, host plants, and life histories of three new Phyllocnistis species from the central highlands of Costa Rica (Lepidoptera, Gracillariidae, Phyllocnistinae). ZooKeys 27: $7-30$.

Kumata, T. 1978. A new stem-miner on alder in Japan, with a review of the larval transformation in the Gracillariidae (Lepidoptera).Insecta
Matsumurana New Series 13: 1-27.

Landry, B. 2006. The Gracillariidae (Lepidoptera, Gracillarioidea) of the Galapagos Islands, Ecuador, with notes on some of their relatives. Revue Suisse de Zoologie 113: 437-485.

Martínez P. \& Donoso, M. 1997. Evaluación, valoración y propuesta de incorporación de los elementos naturales y paisajísticos al centro urbano de Talcahuano. Revista Geográfica de Chile Terra Australis (Instituto Geográfico Militar) 42: 91-99.

Polymeris, C. 1995. Vegetación actual de la Península de Hualpén. Clasificación y dinámica. M. Sc. dissertation. Universidad de Concepción, Concepción, 190 p

Stehr, F. 1987. The immature insects. Dubuque, Kendall/Hunt, 754 p.

Trägardh, I. 1913. Contributions towards the comparative morphology of the trophi of the lepidopterous leaf-miners. Arkiv för Zoologi 8: 1-48.

Vargas, H.A. \& Landry, B. 2005. A new genus and species of Gracillariidae (Lepidoptera) feeding on flowers of Acacia macracantha Willd. (Mimosaceae) in Chile. Acta Entomológica Chilena 29: 47-57.

Vargas, H.A. \& Parra, L.E. 2005. Un nuevo genero y una nueva especie de Oecophyllembiinae (Lepidoptera: Gracillariidae) de Chile. Neotropical Entomology 34: 227-233.

Vargas, H.A., Vargas-Ortiz, M., Huanca-Mamani, W. \& Bobadilla, D. 2013. First Record of Acrocercops serrigera Meyrick (Lepidoptera: Gracillariidae) from Chile. Neotropical Entomology 42: 112-114.

Vari, L. 1961. South African Lepidoptera. Vol. I. Lithocolletidae, Transvaal Museum. Memoir 12, Swets \& Zeitlinger, 238 p.

Wagner, D.L., Loose, J.L., Fitzgerald, T.D., De Benedictis, J. \& Davis, D.R. 2000. A hidden past: the hypermetamorphic development of Marmara arbutiella (Lepidoptera: Gracillariidae). Annals of the Entomological Society of America 93: 59-64. 